\title{
Penetrating injury to the cardiac box and the deadly dozen
}

\author{
Michael Nicoara, David Parizh, Vadim Meytes, Anthony Kopatsis
}

Department of General Surgery, NYU Lutheran, Brooklyn, New York, USA

\section{Correspondence to}

Dr David Parizh, david.parizh@ nyumc.org

Accepted 18 November 2016

CrossMark

To cite: Nicoara $\mathrm{M}$, Parizh D, Meytes V, et al BMJ Case Rep Published online: [please include Day Month Year] doi:10.1136/ bcr-2016-218361

\section{DESCRIPTION}

A man aged 24 years who was assaulted was brought in by paramedics, boarded and collared, as a trauma notification. On primary survey, the patient was breathing spontaneously, saturating well on a non-rebreather mask. He had equal bilateral breath sounds with stable vital signs. On secondary survey, a $3 \mathrm{~cm}$ laceration was noted to the left of the sternal boarder at the fourth ICS. No active bleeding or evidence of sucking wound was evident. FAST examination was equivocal in the trauma bay. After obtaining a chest X-ray to exclude a pneumothorax and widened mediastinum, the patient was taken for a CT scan. Imaging was significant for an anterior $2 \mathrm{~cm}$ thick pericardial fluid collection and pneumomediastinum.

An emergent median sternotomy was performed. Access was obtained in the standard fashion, and the pericardium opened. After evacuating the blood and unroofing the haematoma, a $2 \mathrm{~cm}$ left ventricular linear full thickness laceration injury was noted to be actively bleeding

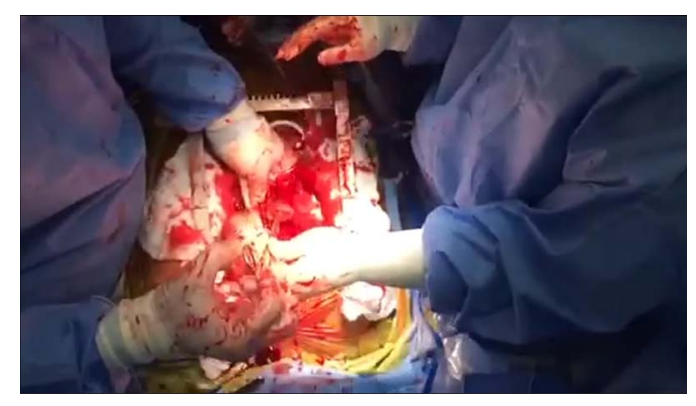

Video 1 Note the degree of exsanguination from a small defect in the left ventricle.

(figure 1 , video 1 ). It was repaired with a pledgetted horizontal mattress using 3-0 prolene sutures (figure 1).

The patient transferred to surgical intensive care unit postoperatively for further monitoring. His hospital course was uneventful, and the patient was discharged home on the fifth hospital day.

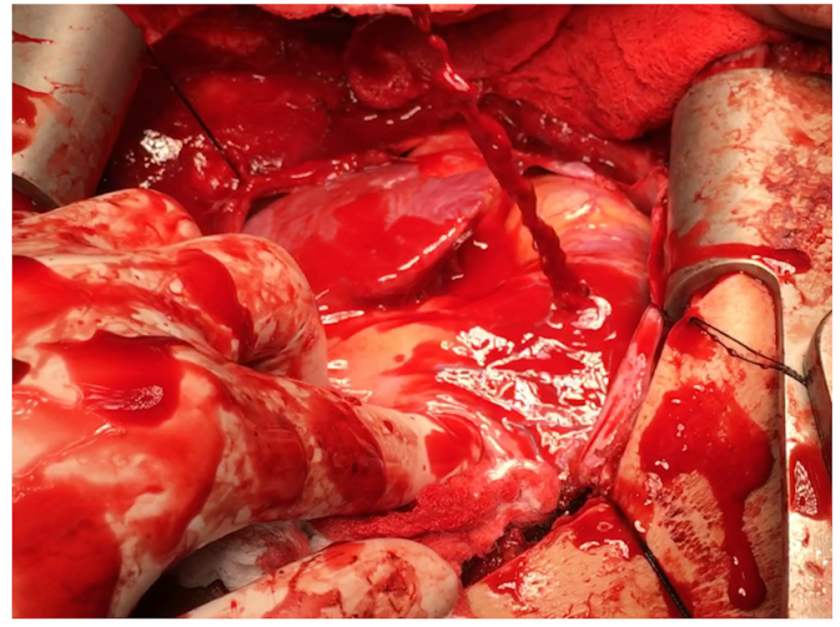

A

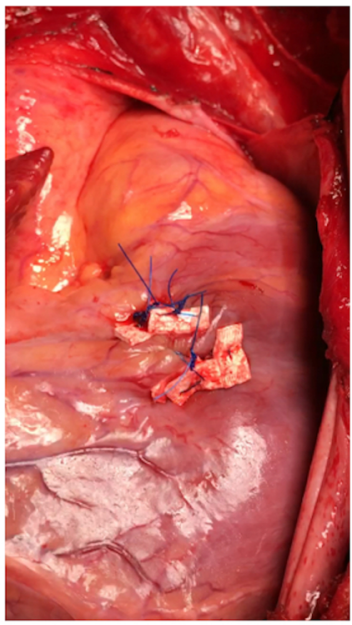

B

Figure 1 Median sternotomy revealing a left ventricular injury sustained from a stab wound $(A)$ which was subsequently repaired (B). 


\section{Learning points}

1. The area bordered by the sternal notch (superior), xiphoid (inferior), nipples (lateral) is referred to as the 'cardiac box'.

2. The 'Deadly Dozen' is a compilation of injuries to be cognizant of in the work-up of a patient with a penetrating injury to the cardiac box. They are further broken down into the lethal six (airway obstruction, open pneumothorax, tension pneumothorax, cardiac tamponade, massive haemothorax, flail chest) and the hidden six (aortic disruption, oesophageal injury, trachiobronchial injury, cardiac contusion, pulmonary contusion, diaphragmatic tear).

3. Stable penetrating trauma to the cardiac box may benefit from screening TTE or CT angiography. Patients with negative results may be monitored. Positive results will need further work-up and operative management as indicated. ${ }^{1}$
Contributors MN contributed to analysis and interpretation of data, drafting the article and final approval of the version to be published. DP contributed to the conception and design of the study, acquired data analysis and interpretation of data, drafting the article, revising intellectual content and final approval of the version to be published. VM contributed to analysis and interpretation of data, drafting the article and final approval of the version to be published. AK contributed to acquired data analysis and interpretation of data, drafting the article and final approval of the version to be published.

Competing interests None declared.

Patient consent Obtained.

Provenance and peer review Not commissioned; externally peer reviewed.

\section{REFERENCE}

1 Burack JH, Kandil E, Sawas A, et al. Triage and outcome of patients with mediastinal penetrating trauma. Ann Thorac Surg 2007;83:377-82.

Copyright 2016 BMJ Publishing Group. All rights reserved. For permission to reuse any of this content visit http://group.bmj.com/group/rights-licensing/permissions.

BMJ Case Report Fellows may re-use this article for personal use and teaching without any further permission.

Become a Fellow of BMJ Case Reports today and you can:

- Submit as many cases as you like

- Enjoy fast sympathetic peer review and rapid publication of accepted articles

- Access all the published articles

- Re-use any of the published material for personal use and teaching without further permission

For information on Institutional Fellowships contact consortiasales@bmjgroup.com

Visit casereports.bmj.com for more articles like this and to become a Fellow 